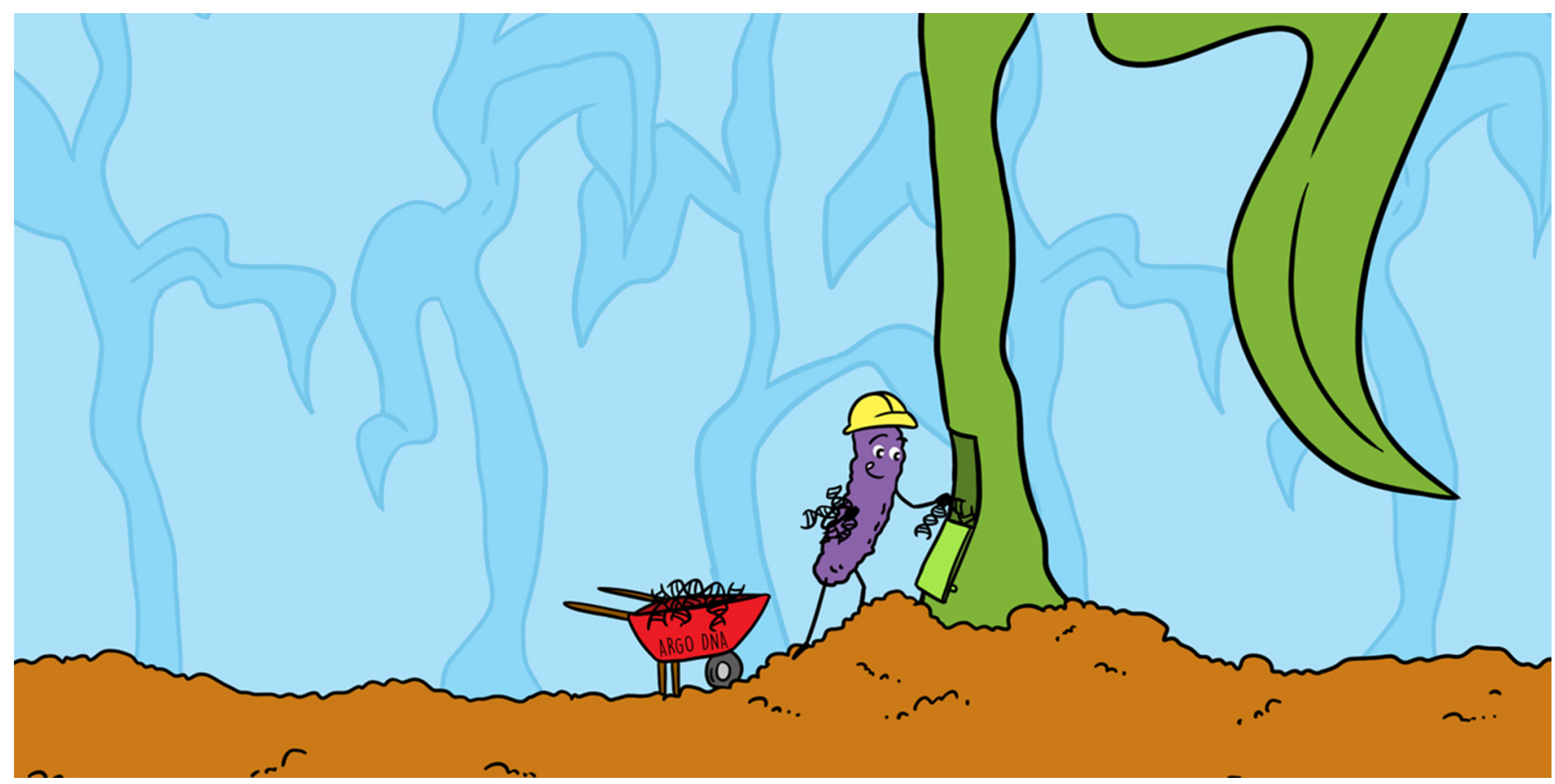

\title{
AGROBACTERIUM: SOIL MICROBE, PLANT PATHOGEN, AND NATURAL GENETIC ENGINEER
}

\section{Ryan T. Weir * and Johnathan J. Dalzell *}

School of Biological Sciences, Queen's University Belfast, Belfast, United Kingdom

YOUNG REVIEWERS: MERCY SCHOOL AGES: $10-11$
Agrobacterium tumefaciens (Agrobacterium for short) is a single-celled microbe and natural genetic engineer. It takes part of its DNA (the blueprint instructions for life, which are found in every living thing), and inserts it into the DNA of a plant! This tricks the plant into protecting and feeding the microbe; this is great for the microbe, but not so great for the plant. The discovery that Agrobacterium inserts its DNA into plants shows us that genetic engineering is a natural process. Scientists can use this technique to easily introduce new DNA sequences into crop plants, which gives the crops new abilities that help them to fight off pests, grow more nutritious food, and become better at dealing with climate change! In this article, we will explore how Agrobacterium makes a genetically modified organism (GMO), and how this process can help us to improve crop plants and grow more food using less land and pesticides.

\section{AGROBACTERIUM FINDS A PLANT}

Agrobacterium tumefaciens (Agrobacterium for short) is a single-celled microbe that lives in the soil. This microbe has the ability to find a 


\section{VIRULENCE}

The ability to infect another organism and cause disease. The word "virulence" gives the name to the Vir genes that help Agrobacterium manipulate plants.

\section{GENOME}

All the DNA instructions that an organism needs to survive and reproduce.

\section{PLASMID}

A DNA sequence that is separate from other DNA instructions in the genome. It is circular and can be copied and shared between microbes. wide range of different plants by moving toward chemicals that are released from naturally occurring plant wounds. Agrobacterium can swim through water films in the soil to reach plants, using structures called flagella, which beat like tails. Although Agrobacterium does not have eyes or ears (these would be of little help in the soil anyway), it does have a number of specialized proteins that identify plant chemicals by acting like a very simple nose, which it uses to sniff out a plant. These proteins allow Agrobacterium to move in the right direction, toward the plant. When Agrobacterium realizes that it is going in the wrong direction, it flaps its flagella randomly, tumbles to point in a new direction, and swims in a straight line. This sequence of swimming and tumbling are repeated until it finds the plant.

Agrobacterium is an expert in communicating with plants, using chemicals rather than words! When the microbe contacts a plant, it releases several different chemicals, which tell the plant to make its surface "sticky." This stickiness allows Agrobacterium to attach to the plant and prepare to invade. At this point, the Agrobacterium switches on a family of Vir (short for "virulence") genes. These Vir genes contain the DNA instructions to make all the tools that Agrobacterium needs to break into the plant cell and smuggle new DNA into the plant cell's nucleus (which contains the plant's genome-all of its DNA instructions). A biological siege has now begun, and the stakes are huge!

\section{AGROBACTERIUM TRANSFERS DNA INTO THE PLANT}

Agrobacterium has a special circular type of DNA, called a plasmid. The small section of DNA that Agrobacterium wants to transfer into the plant genome (called T-DNA, for transfer DNA), is found within the plasmid. One of the Vir genes that is activated when the microbe sticks to the outside of the plant makes a protein called VirD2. VirD2 functions like biological scissors, cutting the T-DNA out of the circular DNA plasmid. VirD2 then attaches to one end of the T-DNA, and drags it into the plant cell, toward the plant nucleus (like a little protein tugboat ... which is also a pair of scissors). Before that can happen, Agrobacterium needs to break through the barrier of the plant cell wall. It does this by building a "syringe" with other virulence proteins, called VirB1 through VirB11, and VirD4. Using this protein syringe, Agrobacterium injects the T-DNA through the plant cell wall.

Plants have learned to protect themselves against this assault, though. When the plant discovers that Agrobacterium is attacking, an army of plant enzymes try to cut up the Agrobacterium T-DNA before it can reach the plant cell nucleus. However, Agrobacterium is one step ahead, having clothed the T-DNA in a protein armor made of another virulence protein, called VirE2, which prevents the plant enzymes from getting hold of the T-DNA. Once the T-DNA makes it to the plant cell nucleus, it looks for breaks in the DNA (these occur naturally) and 
Figure 1

Agrobacterium can manipulate plant cells by inserting new DNA sequences. Chemicals from a plant wound attract Agrobacterium and trigger the invasion process. T-DNA is cut from the DNA plasmid in Agrobacterium and is injected into the plant cell. From here, the T-DNA is transported toward the plant cell nucleus, where it is imported and inserted into the plant genome (not drawn to scale; adapted from Williams and Yuan [1]).

\section{GENETICALLY \\ MODIFIED \\ ORGANISM}

An organism that has been beneficially modified through the addition of new

DNA instructions.

\section{CROWN GALL}

The characteristic growth that can be seen on plants when they have been infected by Agrobacterium.

\section{PATHOGEN}

A pathogen is an organism that causes disease in another organism.

Agrobacterium is naturally a pathogen of plants.

\section{GENETIC \\ ENGINEERING}

The process of making known and specific changes to the DNA sequence of an organism; also called genetic modification.

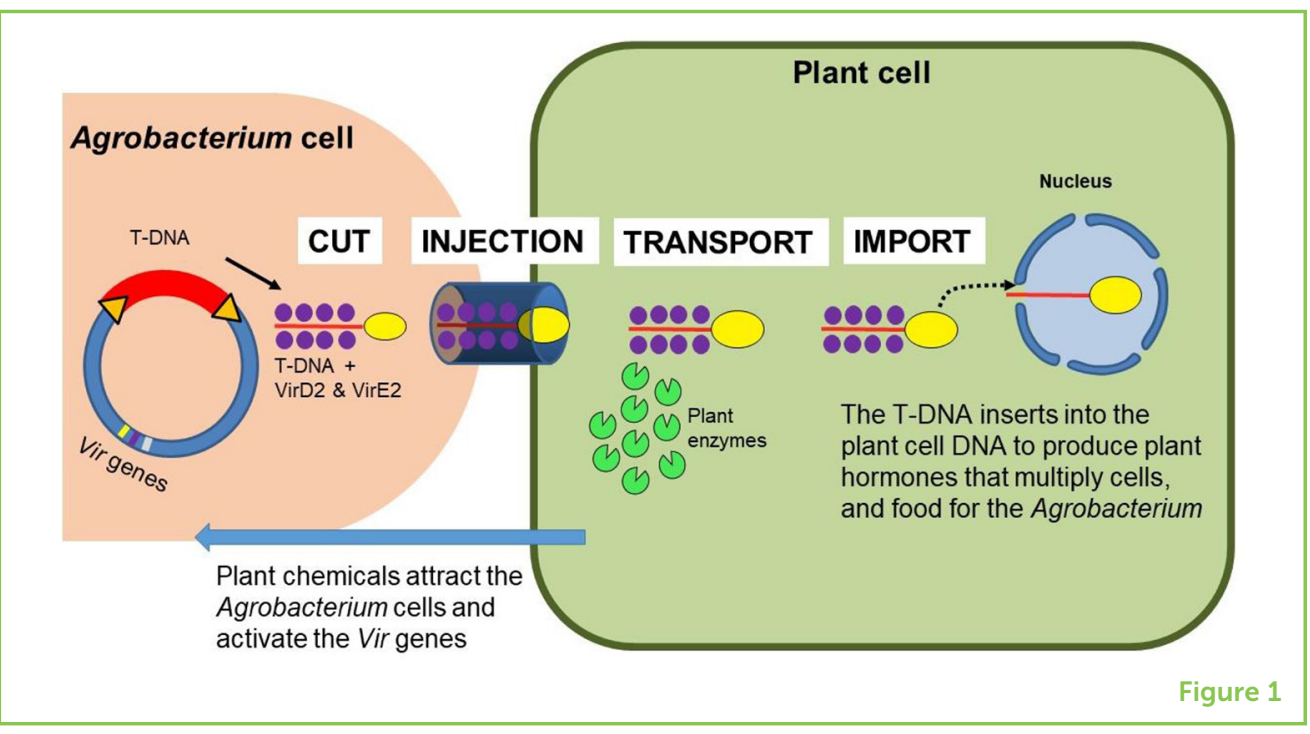

inserts itself into the DNA as the plant cell repairs the DNA break. When this happens, the plant cell becomes genetically modified, as it now contains DNA instructions from another organism (the Agrobacterium) that will change how the plant behaves and works (Figure 1) -the plant is now a genetically modified organism (GMO)!

\section{AGROBACTERIUM MANIPULATES THE PLANT}

The T-DNA that Agrobacterium inserts into the plant genome contains instructions that will be copied into every cell that develops from this first genetically modified cell. In fact, some of the new DNA instructions stimulate the plant cell to divide and reproduce, forming large galls, which you can see as unusual growths in the plant (Figure 2). This is actually how Agrobacterium was first discovered-it was found to cause a plant disease called crown gall disease, which limits the growth and yield of crop plants. The Agrobacterium T-DNA triggers gall formation by changing the amount of certain plant hormones, which creates a safe environment for the microbe. On top of that, the T-DNA also codes for a recipe: instructions to make Agrobacterium's favorite food. Agrobacterium feeds on a family of chemicals that most plants do not know how to make. When the Agrobacterium inserts its T-DNA instructions into the plant DNA, it is basically sharing a favorite family recipe with the plant. In summary, Agrobacterium invades the plant, manipulates its DNA, and inserts new instructions that tell the plant how to protect and feed it! While Agrobacterium benefits from this interaction, the plant does not. Agrobacterium is classed as a pathogen, because it causes disease (also known as pathology) in the plant.

\section{AGROBACTERIUM CAN HELP US TO IMPROVE PLANTS}

From what we have told you so far, you can see that genetic engineering is a natural process that Agrobacterium uses to 
Figure 2

Agrobacterium causes crown gall disease in many plants. This picture shows the galled tissue of a mango tree, caused by infection with Agrobacterium. When the microbe infects a plant and inserts its DNA, this forces the plant to produce hormones that multiply the cells and gives the plant cells everything they need to feed the pathogen.

Agrobacterium lives inside the galls.

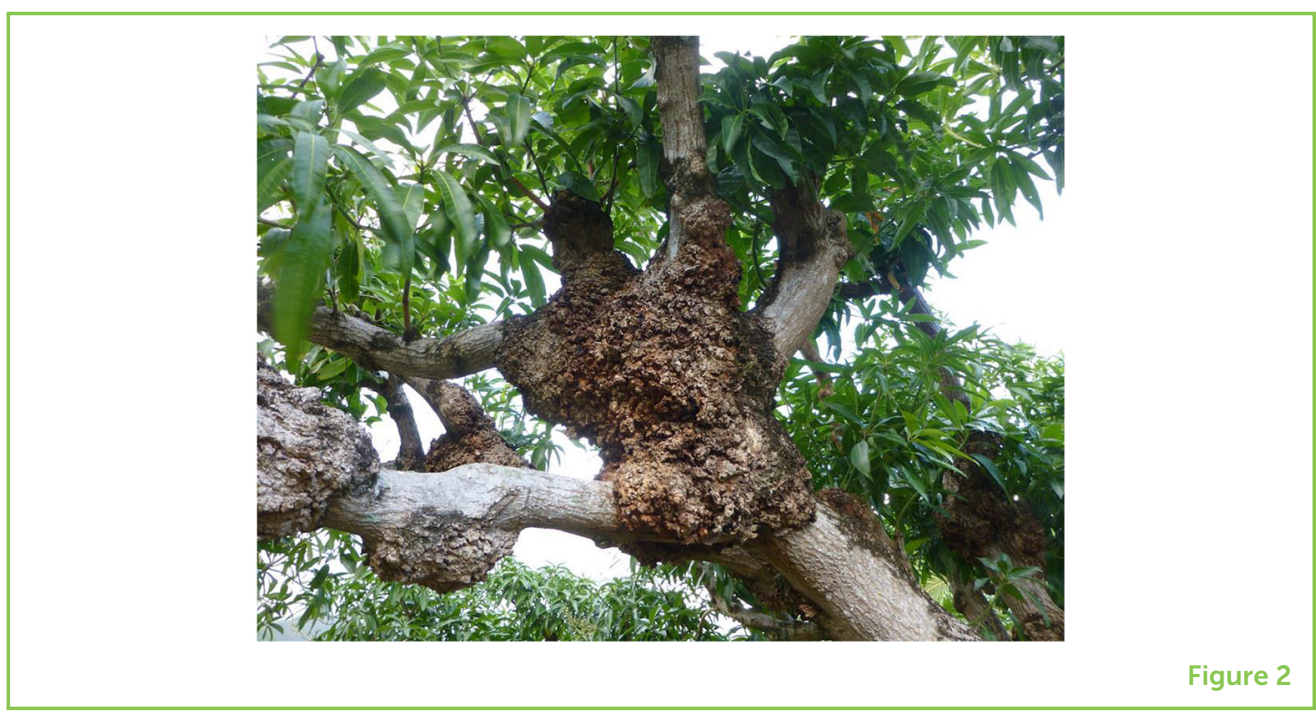

manipulate plants. In fact, there is good evidence that many different plants have kept parts of the T-DNA after Agrobacterium infection [2]. Scientists can alter Agrobacterium T-DNA to remove all of the instructions that harm the plant, and replace them with new DNA instructions that will help the plant! Many successful plants have resulted from this process: crops that are resistant to insect pests [3]; papaya that is resistant to a devastating virus that would have destroyed farms all over Hawaii [4]; golden rice that is fortified with a chemical that we need to make vitamin $A$, which could prevent millions of children from going blind [5]; non-browning, healthier potatoes that reduce food waste [6]; and many others (Figure 3).

Despite the many benefits of using Agrobacterium to improve crop plants, some groups seek to prevent the use of genetic engineering, and even try to misinform the public about the approach. One of the most common misunderstandings about genetic engineering is the belief that changing the DNA of an organism is unnatural and therefore wrong. However, Agrobacterium has been modifying the DNA of plants long before humans learned how to do it. This shows us that changing DNA sequences is a natural process and part of the world around us. By using Agrobacterium to modify plant DNA, we are harnessing a natural process to develop crop plants that need fewer pesticides, are more nutritious, and that yield more food using less land. Using less land is a really important consideration because, if we want to avoid the destruction of natural ecosystems, we need to make sure that our farms are as productive as possible. Genetically engineered crop plants can definitely help us to grow more food from less land, meaning that more ecosystems will be protected. Also, long-term studies confirm that genetically modified crops are safe to eat [7]. Despite what some groups opposed to GMOs say, genetically modified crops are no more dangerous than any other crop we eat! 
Figure 3

A genetically engineered tomato plant being grown in the laboratory. This picture shows a young tomato plant that has been genetically engineered. Agrobacterium was used to insert new DNA into small pieces of tomato plant leaf tissue. The modified cells were then encouraged to grow into a plant by changing the amounts of certain hormones available in the specialized gel that we grow the plant cells in. Roots have started to grow from this tomato plant, which will shortly be taken from this protective container and grown in soil.

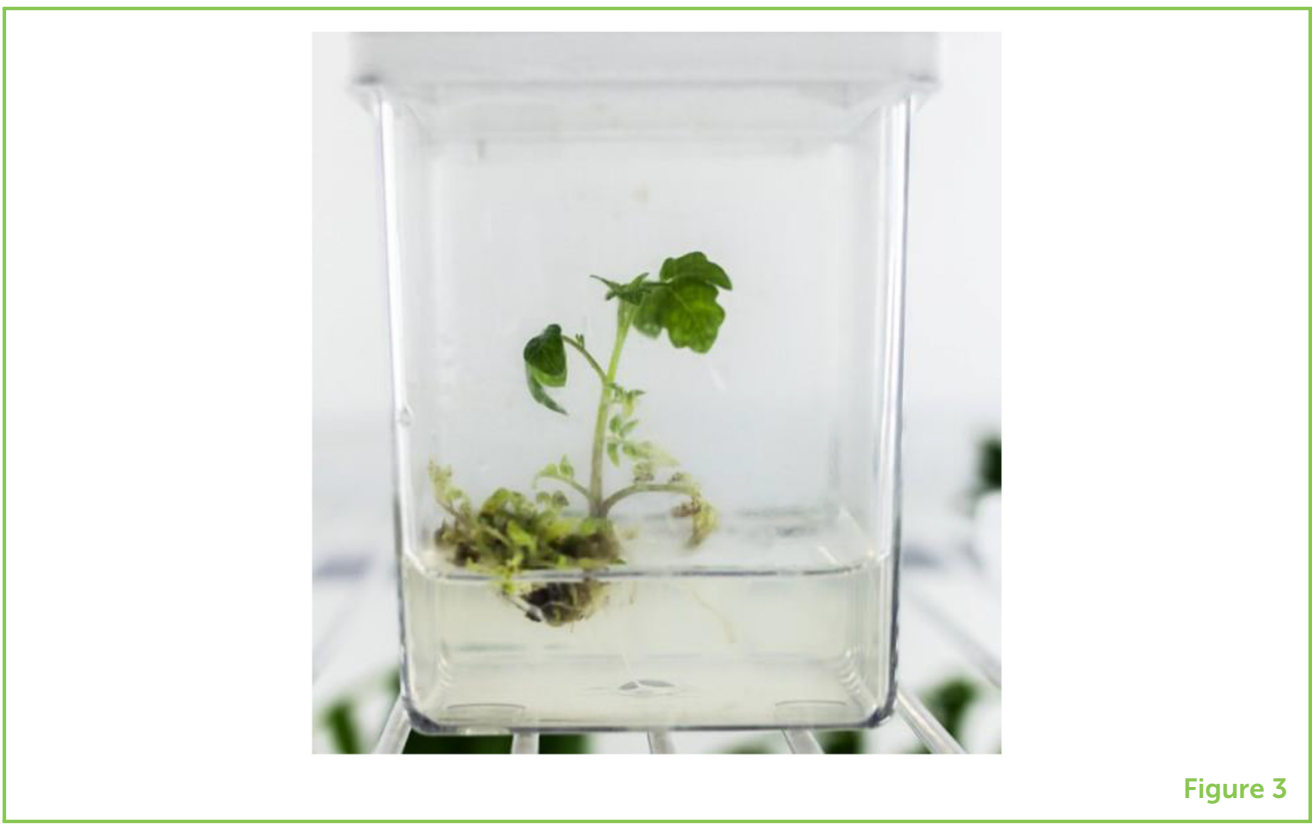

\section{CONCLUSIONS}

Agrobacterium is a soil microbe, a plant pathogen, and a genetic engineer. Through understanding the biology of natural genetic modification, we can better understand the process used to develop genetically modified plants, or other kinds of GMOs. Agrobacterium allows us to make beneficial changes to the DNA of plants, which ultimately means we can grow more nutritious food using less land, which protects our environment. If you want to learn more about the process of making a GMO, you can watch the fantastic video by Science IRL at https://www.youtube.com/watch?v=-b_Un-IGSWo.

\section{REFERENCES}

1. Williams, M. E., and Yuan, Z. C. 2012. A really useful pathogen, Agrobacterium tumefaciens. Plant Cell 24:tpc.112.tt1012. doi: 10.1105/tpc.112.tt1012

2. Matveeva, T. V., and Otten, L. 2019. Widespread occurrence of natural genetic transformation of plants by Agrobacterium. Plant Mol. Biol. 101:415. doi: 10.10 07/s11103-019-00913-y

3. Vaeck, M., Reynaerts, A., Höfte, H., Jansens, S., De Beuckeleer, M., Dean, C., et al. 1987. Transgenic plants protected from insect attack. Nature 328:33-7. doi: 10. $1038 / 328033 a 0$

4. Jia, R., Zhao, H., Huang, J., Kong, H., Zhang, Y., Guo, J., et al. 2017. Use of RNAi technology to develop a PRSV-resistant transgenic papaya. Sci. Rep. 7:12636. doi: 10.1038/s41598-017-13049-0

5. Ye, X. D., Al-Babili, S., Kloti, A., Zhang, J., Lucca, P., Beyer, P., et al. 2000. Engineering the provitamin A (beta-carotene) biosynthetic pathway into (carotenoid-free) rice endosperm. Science 287:303-5. doi: 10.1126/science. 287.5451.303 
6. Rommens, C. M., Ye, J., Richael, C., and Swords, K. 2006. Improving potato storage and processing characteristics through all-native DNA transformation. J. Agric. Food Chem. 54:9882-7. doi: 10.1021/jf062477l

7. The National Academies of Sciences, Engineering and Medicine. 2016. Genetically Engineered Crops: Experiences and Prospects. Washington, DC: The National Academies Press. doi: 10.17226/23395

SUBMITTED: 06 November 2019; ACCEPTED: 14 April 2020; PUBLISHED ONLINE: 21 May 2020.

EDITED BY: Phillip R. Myer, The University of Tennessee, Knoxville, United States

CITATION: Weir RT and Dalzell JJ (2020) Agrobacterium: Soil Microbe, Plant Pathogen, and Natural Genetic Engineer. Front. Young Minds 8:64. doi: 10.3389/ frym.2020.00064

CONFLICT OF INTEREST: The authors declare that the research was conducted in the absence of any commercial or financial relationships that could be construed as a potential conflict of interest.

COPYRIGHT @ 2020 Weir and Dalzell. This is an open-access article distributed under the terms of the Creative Commons Attribution License (CC BY). The use, distribution or reproduction in other forums is permitted, provided the original author(s) and the copyright owner(s) are credited and that the original publication in this journal is cited, in accordance with accepted academic practice. No use, distribution or reproduction is permitted which does not comply with these terms.

\section{YOUNG REVIEWERS}

\section{MERCY SCHOOL, AGES: 10-11}

We are an inventor class! We love to build and create in order to find solutions to real world problems. Our students come from all over the area to attend school.

\section{AUTHORS}

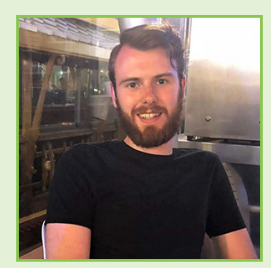

\section{RYAN T. WEIR}

Ryan Weir is a final year undergraduate student at Queen's University Belfast, completing a degree in microbiology. He took a year out from his studies to work with Johnathan, contributing to several research projects and scientific papers. He has experience using Agrobacterium to genetically engineer plants and has been developing ways to stop Agrobacterium from finding plants in the soil. Ryan is passionate about how genetic engineering can give crop plants the upper hand in the arms races between plants and pathogens, and he is hoping to secure a Ph.D. studentship next year, to study this further. *rweir12@qub.ac.uk 


\section{JOHNATHAN J. DALZELL}

Johnathan Dalzell is a senior lecturer in plant-parasite interactions and biochemistry programme director at Queen's University Belfast. He is interested in studying how plants interact with parasites and microbes. His research group uses Agrobacterium to develop genetically engineered plants that help investigate these interactions. He is also an advocate for genetically modified/engineered crops as part of the solution to global food insecurity, and he hopes to persuade everyone that this is a safe and beneficial technique. *j.dalzell@qub.ac.uk 